\title{
Septal Pores in Endomycopsis platypodis and Endomycopsis monospora
}

\author{
By N. J. W. KREGER-VAN RIJ \\ Laboratory of Bacteriology and Serology, State University, \\ Groningen, The Netherlands \\ AND M. VEENHUIS \\ Laboratory of Ultrastructural Biology, State University, \\ Haren, The Netherlands
}

(Accepted for publication 17 March 1969 )

SUMMARY

In ultra thin sections of hyphae of the yeast species Endomycopsis platypodis and $E$. monospora septal pores were observed with the electron microscope. The pores are enclosed by a swelling of the cross-wall. Electron-dense bodies plug the pores; these bodies are surrounded by a membrane which is connected with the endoplasmic reticulum and which also connects the plugs at both sides of the cross-wall via the pore.

\section{INTRODUCTION}

The ascogenous yeast species Endomycopsis platypodis Baker et Kreger-van Rij (1964) and $E$. monospora Saito (1932) produce abundant true mycelium as well as budding cells, a combination of features which characterizes the genus Endomycopsis. Classification of these species in Endomycopsis is, however, not generally accepted. Fiol (1967) transferred E. platypodis to the genus Hansenula as defined by Wickerham (I95I). This genus comprises all nitrate-positive species with hat- or saturn-shaped spores; and Wickerham included in it both yeasts which do and yeasts which do not form true mycelium. Boidin, Pignal \& Besson (1965) followed him by classifying species with and without true mycelium in the similar genus, Pichia, members of which do not utilize nitrate. One of these species was Pichia (Endomycopsis) fasciculata. These authors did not consider that the formation of true mycelium was a suitable character for distinguishing between genera. Although this point of view either necessitated the abolition of the genus Endomycopsis or required its redefinition for those species which were not reclassified, neither measure was undertaken. Unlike Wickerham or Boidin and his colleagues, Kreger-van Rij (1964) retained the genus Endomycopsis in its original shape, because most of its species have different features from those of species of the genera Hansenula or Pichia in addition to the formation of abundant true mycelium. Adequate studies have yet to be made on changes in fine structure associated with the formation of true mycelium on the one hand and with pseudomycelium on the other. The only ultrastructural studies of mycelium in Endomycopsis species are probably those of Takada, Yagi \& Hiroaka (1965), who described the occurrence of plasmodesmata in the cross-walls of E. fibuligera, and of Besson (1967), 
who observed plasmodesmata in $E$. capsularis. In the present work the observation of septal pores in $E$. platypodis and $E$. monospora is reported. Some additional species, thought to be related to E. platypodis and E. monospora, have been examined for comparison.

\section{METHODS}

The following strains were used:

Endomycopsis platypodis Baker et Kreger-van Rij, CBS 4I I I F Elatypodis Baker et Kreger-van Rij, Y-6IoI from Dr L. J. Wickerham, CBS 5560; E. monospora Saito, CBS 2554; E. monospora Saito, strain Endomycopsis fasciculata Batra, CBS 55I4; E. bispora (Beck) Dekker, CBS I890; E. fibuligera (Lindner) Dekker, CBS 5190; E. vini Kreger-van Rij, CBS 4377; Cephaloascus fragrans Hanawa, strain Ascocybe grovesii Wells.

The organisms were grown on malt agar, corn meal agar or on a medium containing $0.3 \%$ yeast extract, $0.5 \%$ peptone, I $\%$ glucose and $2 \%$ agar. Young cultures were fixed (I) according to the method of Ryter \& Kellenberger (1958) in I \% osmic acid in veronal + acetate buffer ( $\mathrm{pH}$ 6) for $16 \mathrm{hr}$, and, after washing with Kellenberger buffer, in $0.5 \%$ uranyl acetate for one $\mathrm{hr}$, both at room temperature, or (2) in $\mathrm{I} \cdot 5 \%$ aqueous unbuffered $\mathrm{KMnO}_{4}$ solution for $20 \mathrm{~min}$. at room temperature. After dehydration in an acetone series, embedding was done in Vestopal $\mathrm{W}$ at $60^{\circ}$. Ultra thin sections were cut with a diamond knife on an LKB Ultrotome. Part of the sections was stained with lead citrate (Reynolds, 1963 ) for $3 \mathrm{~min}$. or with $\mathrm{I} \cdot 5 \% \mathrm{KMnO}_{4}$ solution for $30 \mathrm{~min}$. They were examined with a Philips EM roo electron microscope.

\section{RESULTS}

The hyphae of Endomycopsis platypodis in serial sections show septa with central pores (Fig. I ; Pl. I and 2). The septa are slightly bulging. The edge of the septum around the pore is swollen. The swelling diminishes abruptly at the concave side and gradually at the convex side of the cross-wall. Together with the pore the swelling constitutes the greater part of the septum. The central layer of the septal plate is electron-light, the adjacent layers including the swelling are relatively electron-dense. In longitudinal sections the swelling shows a fibrillar structure (P1. 2, fig. 8); in cross-sections through the cross-wall the fibrils are observed as concentric rings (Pl. 2, fig. 9). The plasmalemma, showing as two thin dark lines with a light interspace, lines the protoplast and is continuous through the pore. Two dark bodies plug the pore at each side. They are surrounded by a membrane which envelops them both; the connexion of the plugs is formed by a narrow channel through the pore (Pl. I, fig. 4). The double membrane of the endoplasmic reticulum lies parallel to the lateral cell wall and the cross-wall. Over the pore the endoplasmic reticulum is continuous in such a way that the plugs seem to be dilatations of it (Pl. I, fig. 2 and 4). Connexions between the membrane of the plugs with other endoplasmic reticulum than the cortical form were also found to occur (Pl. 2, fig 7 and II). Occasionally, a continuous double membrane of endoplasmic reticulum, connected with the cortical endoplasmic reticulum, was observed lying over the plugged pore (Pl. I, fig. 5), but this was never in the shape of the thicker, perforated endoplasmic reticulum which forms the septal pore cap of the Basidiomycetes. The plug at the concave side of the cross-wall was generally observed to be lying against the wall, the one at the convex side at some distance from the wall. 
The septal pores were observed in the hyphae of the yeast. These hyphae do not split up into arthrospores. Between the asci, which are situated terminally or laterally on the hyphae, often in short chains, pores were also present. In budding cells, whether loose or in small chains, the wall formed between mother cell and bud was usually thin. Budding cells formed on the hyphae which did not turn into asci (blastospores) have not yet been examined.

The swellings in the septa were clearly seen by light microscopy (Pl. 3, fig. 15). Formation of a new septum, observed from a first vague indication to a distinct line, occurred within $8 \mathrm{~min}$. It took about an hour until a swelling became visible.

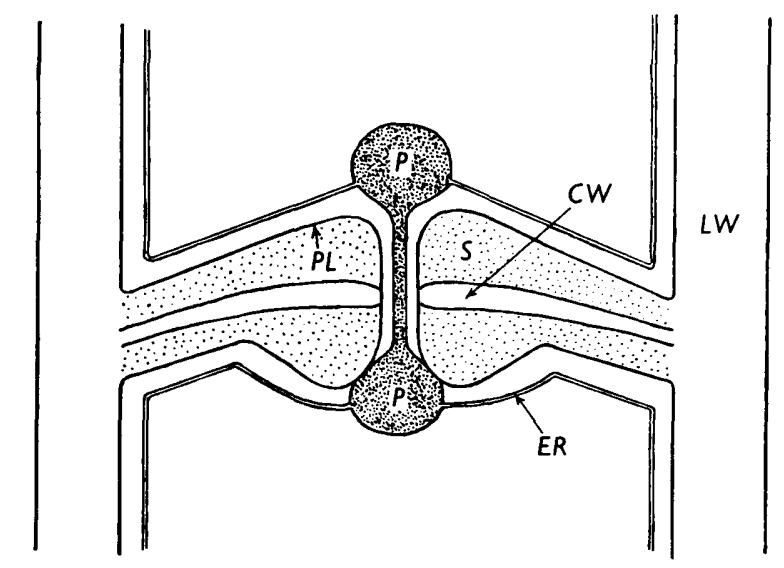

Fig. I. Diagram of a longitudinal section of a septal pore in Endomycopsis platypodis and $E$. monospora. $L W=$ lateral wall, $C W=$ cross-wall, $S=$ swelling, $P L=$ plasmalemma, $P=$ plug, $E R=$ endoplasmic reticulum.

Septal pores were observed in the two strains of Endomycopsis platypodis studied, in the strain of $E$. monospora (CBS 2554), and in a strain of $E$. fasciculata, which is considered to be synonymous with $E$. monospora. In $E$. bispora no septal pores were observed. The hyphae of Cephaloascus fragrans showed simple pores of the Ascomycete type ( $\mathrm{Pl}$. 3, fig. I2). No Woronin bodies but small dense granules as described by Brenner and Carroll (1968) were found in the material examined (P1. 3, fig. 13). The strains of $E$. fibuligera and $E$. vini (Pl. 3, fig. 14) had plasmodesmata as connexions between the cells of the hyphae.

\section{DISCUSSION}

A central pore surrounded by the swollen edge of the cross-wall observed in hyphae of Endomycopsis platypodis and E. monospora greatly resembles the pores found in Basidiomycetes (Girbardt, 1958, 1961; Moore \& McAlear, 1962; Bracker \& Butler, 1963, 1964; Wilsenach \& Kessel, 1965; Giesy \& Day, 1965; Berliner \& Duff, 1965; Hyde \& Walkinson, 1966), the 'dolipore' of Moore \& McAlear (I962). In contrast with the Basidiomycete-type pore, no pore cap was observed in the yeasts. On the other hand, all pores were found to be plugged. For the Basidiomycetes, Bracker \& Butler (1963) are the only authors to mention the occurrence of plugs, which they found in hyphae from old cultures of Rhizoctonia solani. The plugs were amorphous and electron-dense while the inside of the pore was also occluded with electron-dense 
material. The picture of these plugs does not show a membrane surrounding them. In Ascomycetes, Woronin bodies have been described as plugs of septal pores in Fusarium spp. (Reichle \& Alexander, 1965) and in Ascodesmis sphaerospora (Brenner \& Carroll, 1968). These bodies are electron-dense and they are surrounded by a single membrane. Brenner \& Carroll (1968) suggested that they may be dilated cisternae of the endoplasmic reticulum. The plugs of the yeasts bear some resemblance to the Woronin bodies. However, the number of the latter at each side of the pore may be two to four in electron micrographs (Reichle \& Alexander, 1965) while in the yeasts only one plug was found at each side.

According to Bracker \& Butler (1963), the septal swelling differs chemically and physically from the walls. In adjacent cells without protoplasm the cross-wall was found to be intact, but the swelling not present. We observed the same in dead hyphae of Endomycopsis monospora.

Two kinds of septal pore have been found in the fungi, namely the Ascomycete type and the Basidiomycete type. Several authors are inclined to attach taxonomic importance to this feature, and to consider its phylogenetic significance. In this respect, it is surprising to find in yeast species, classified as Ascomycetes, a type of pore which resembles that of the Basidiomycetes. On the other hand, lack of a pore cap on this type of pore is a new observation, as is the probably permanent presence of plugs.

The yeast strains in which the dolipores have been observed belong to two different species which are, however, similar in several respects. They differ with respect to the ability to utilize nitrate, so that authors who do not accept the genus Endomycopsis must classify the two species in different genera, as Hansenula platypodis and Pichia monospora. It remains to be seen whether dolipores occur in the hyphae of other Hansenula and Pichia species; and if this were not so, it must be asked to which property, presence of dolipores or utilization of nitrate, priority should be given for reclassification. For the present, it is preferred to retain the species in question in the genus Endomycopsis.

Dr L. J. Wickerham (personal communication) drew attention to the resemblance between the aerial ascophores of Cephaloascus fragrans and the hyphae that bear asci in Endomycopsis platypodis. He believed that there is a somewhat distant relationship between the two species, although he was quite aware of the differences in structure of the ascophores of $C$. fragrans and $E$. platypodis. The finding of simple pores of the Ascomycete type in $C$. fragrans by Besson (1967) and by the present authors and of dolipores in $E$. platypodis emphasizes the differences between the two species.

In a third Endomycopsis species, E. bispora, which Kreger-van Rij (I964) considered to be related to $E$. platypodis and E. monospora, no dolipores were found. Two other related species, Endomycopsis fibuligera and $E$. vini, did not show dolipores either. We found plasmodesmata in the cross-walls of $E$. fibuligera as Takada et al. (1965) did, and E. vini, which closely resembles E. fibuligera, also had plasmodesmata.

There is no doubt that the genus Endomycopsis in its present definition (Kreger-van $\mathrm{Rij}, \mathrm{1964}$ ) is heterogeneous. There is, however, something to be said for retaining this taxon until several of its features, such as the production of true mycelium and buds, have been more closely examined. 
We are indebted to Dr J. Boddingius for making the light micrograph. Our thanks are due to Dr J. A. Barnett for corrections of the English text. The first author wishes to acknowledge the hospitality of the Laboratory of Ultrastructural Biology of the State University of Groningen.

\section{REFERENCES}

BAKER, J. M. \& KREGER-VAN RIJ, N. J. W. (1964). Endomycopsis platypodis sp.n. (Ascomycetes): an auxiliary ambrosia fungus of Platypus cylindrus Fab. (Col. Platypodidae). Antonie van Leeuwenhoek 30, 433.

Berliner, M. D. \& Duff, R. H. (1965). Ultrastructure of Armillaria mellea hyphae. Can. J. Bot. 43, 171 .

Besson, M. (1967). La fructification d'Ascocybe grovesii Wells (= Cephaloascus fragrans Hanawa) au microscope électronique. Extr. Bull. mens. Soc. linn. Lyon 36, 230.

Boidin, J., Pignal, M. C. \& Besson, M. (1965). Le genre Pichia sensu lato (Quatrième contribution). Bull. Soc. mycol. Fr. 8r, 566.

BraCKer, C. E. \& BUTLER, E. E. (1963). The ultrastructure and development of septa in hyphae of Rhizoctonia solani. Mycologia 55, 35.

Bracker, C. E. \& Butuer, E. E. (1964). Function of the septal pore apparatus in Rhizoctonia solani during protoplasmic streaming. J. Cell Biol. 2r, 152.

Brenner, D. M. \& CARroll, G. C. (I968). Fine-structural correlates of growth in hyphae of Ascodesmis sphaerospora. J. Bact. $95,658$.

FroL, J. B. (1967). Les besoins vitaminiques dans les genres Debaryomyces Kloecker, Schwanniomyces Kloecker, Hansenula H, et P. Sydow et Endomycopsis Dekker. C. r. hebd. Séanc. Acad. Sci., Paris, (sér. D) 264, I605.

GiesY, R. M. \& DAY, P. R. (1965). The septal pores of Coprinus lagopus in relation to nuclear migration. Am. J. Bot. 52, 287.

Girbardt, M. (1958). Uber die Substruktur von Polystictus versicolor L. Arch. Mikrobiol. $28,255$.

GIRBARDT, M. (1961). Licht und elektronen mikroskopische Untersuchungen an Polystictus versicolor. II. Die Feinstruktur von Grundplasma und Mitochondrien. Arch. Mikrobiol. 39, 35 I.

HYDE, J. M. \& WaLKInson, C. H. (1966). Ultrastructure of basidiospores and mycelium of Lenzites saepiaria. J. Bact. 92, 1218.

Kreger-VAN RIJ, N. J. W. (1964). A taxonomic study of the yeast genera Endomycopsis, Pichia and Debaryomyces. Thesis, University of Leiden.

MOORE, R. T. \& MCAlear, J. H. (1962). Fine structure of mycota. 7. Observations on septa of Ascomycetes and Basidiomycetes. Am. J. Bot. 49, 86.

REICHLE, R. E. \& AlEXANDER, J. V. (1965). Multiperforate septations, Woronin bodies, and septal plugs in Fusarium. J. Cell Biol. 24, 489.

ReYNolds, E. S. (1963). The use of lead citrate at high $\mathrm{pH}$ as an electron opaque stain in electron microscopy. J. Cell Biol. r7, 208.

RYTER, A. \& Kellenderger, E. (1958). Etude au microscope électronique do plasmas contenant de l'acide désoxyribonucléique. I. Les nucléotides des bactéries en croissance active. $Z$. Naturforsch. 13 $b, 597$.

SATro, K. (1932). Journal of Brewery Science ro, I I (in Japanese).

TAKADA, H., YAGI, T. \& HIROAKA, J. (1965). Elektronenoptische Untersuchungen an Endomycopsis fibuliger auf festen Năhrböden. Protoplasma 59, 494.

WiCkerham, L. J. (1951). Taxonomy of yeasts. Tech. Bull. U.S. Dep. Agric. no. 1029.

Wilsenach, R. \& KeSsel, M. (1965). On the function and structure of the septal pore of Polyporus rugulosus. J. gen. Microbiol. 40, 397. 


\section{EXPLANATION OF PLATES}

Symbols: $C W=$ cross-wall, $S=$ swelling, $P L=$ plasmalemma, $P=$ plug, $E R=$ endoplasmic reticulum. In Fig. I to I 4 the marker represents $0.5 \mu$, in Fig. I5, $5 \mu$. The figures of Plate I and 2 are hyphae fixed with $\mathrm{KMnO}_{4}$ and post-stained with lead, unless otherwise indicated.

\section{Plate I}

Fig. I to 5. Longitudinal sections of hyphae of E. platypodis.

Fig. I. Six serial sections through a septal pore.

Fig. 2. Section showing connexions between plug- and ER membranes. Note continuity of plasmalemma through the pore.

Fig. 3. Section of material fixed with osmic acid and uranyl acetate, and post-stained with lead.

Fig. 4. Section through a pore showing continuity of ER with plug membrane and connexion of the two plugs via the pore.

Fig. 5. Cortical ER lying over the plug.

\section{Plate 2}

Fig. 6 to 7 and ro to I I are longitudinal sections of hyphae of E. platypodis, Fig. 8 of E. monospora.

Fig. 6. Section showing the position of the plugs, the one at the concave side close to the wall, the one at the convex side at some distance from it.

Fig. 7. The ER system is more complicated and at several points connected with the plugs.

Fig. 8. The swelling shows a fibrillar structure.

Fig 9. In cross-section, the swelling (S) shows more or less a structure of concentric rings. Within the pore the tubular connexion of the two plugs is visible. The swelling is partly surrounded by the plasmalemma and by strands of endoplasmic reticulum.

Fig. 10. Oblique section through a pore with only one plug visible. The ER lies parallel to the crosswall.

Fig. I I. Similar section through the same pore with both plugs visible.

\section{Plate 3}

Fig. 12 to 14 are fixed with osmic acid and uranyl acetate and post-stained with lead.

Fig. I 2 and 13. Longitudinal sections through hyphao of Cephaloascus fragrans. A simple central pore is present, with small dense granules in the vicinity, clearly seen in Fig. I3.

Fig. 14. Longitudinal section through a hypha of Endomycopsis vini. Several plasmodesmata are visible connecting the protoplasts of adjacent cells.

Fig. I5. Light micrograph of a hypha of Endomycopsis platypodis. In the cross-wall the swelling shows as a dark ring with a light centre. 


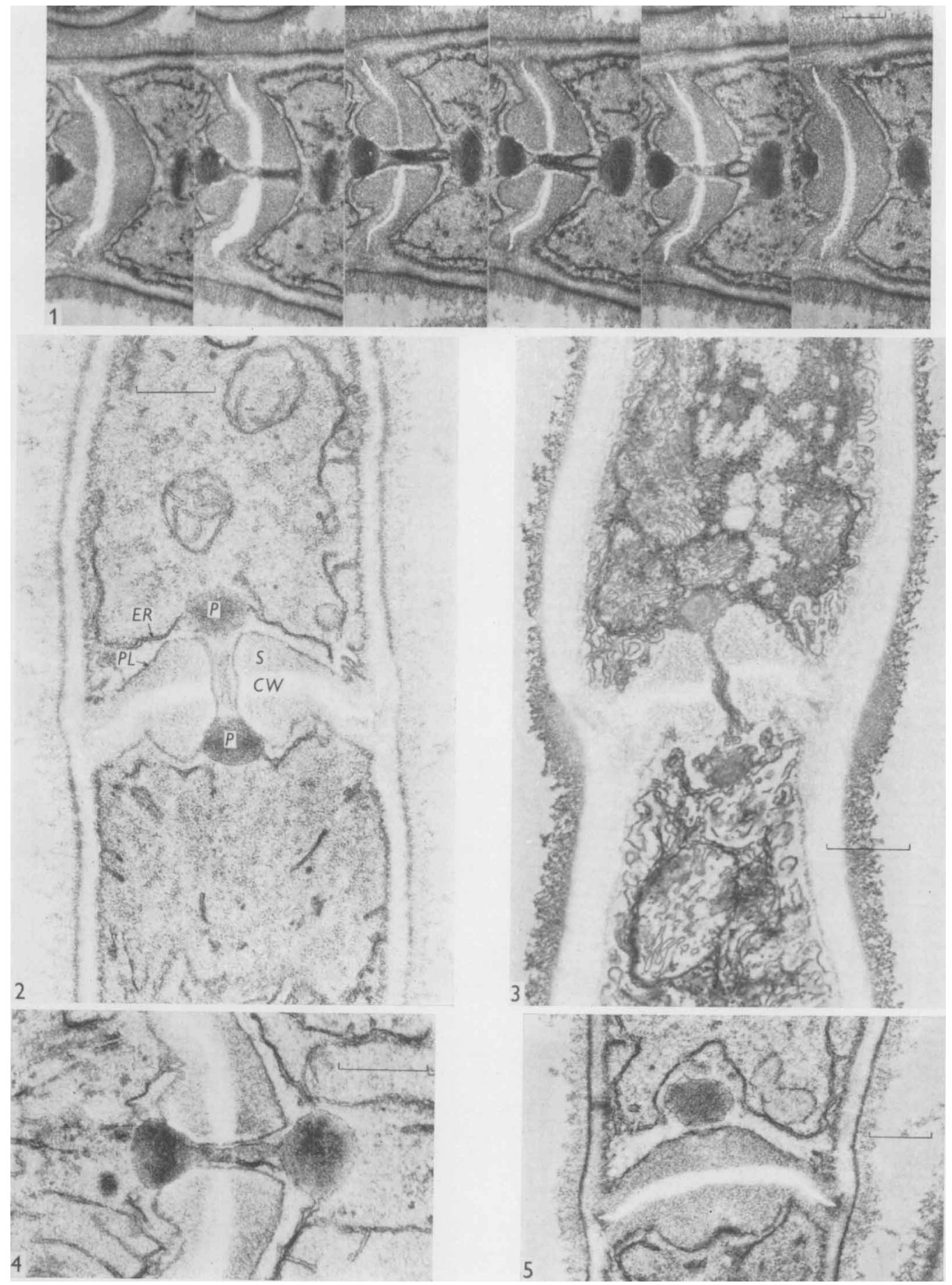



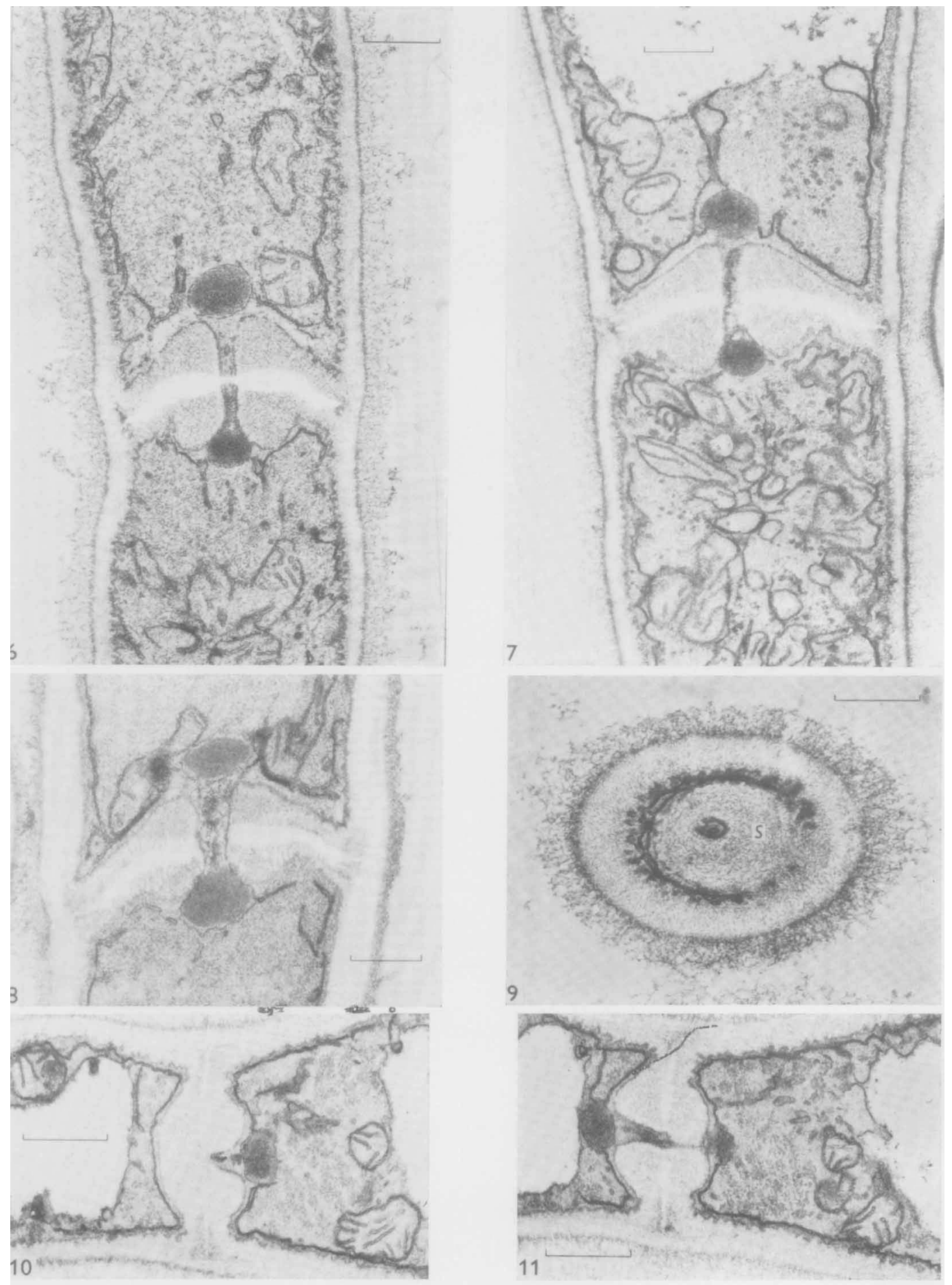

N. J. W. KREGER-vAN RIJ AND M. VEENHUIS 
Journal of General Microbiology, Vol. 57, No. I

Plate 3
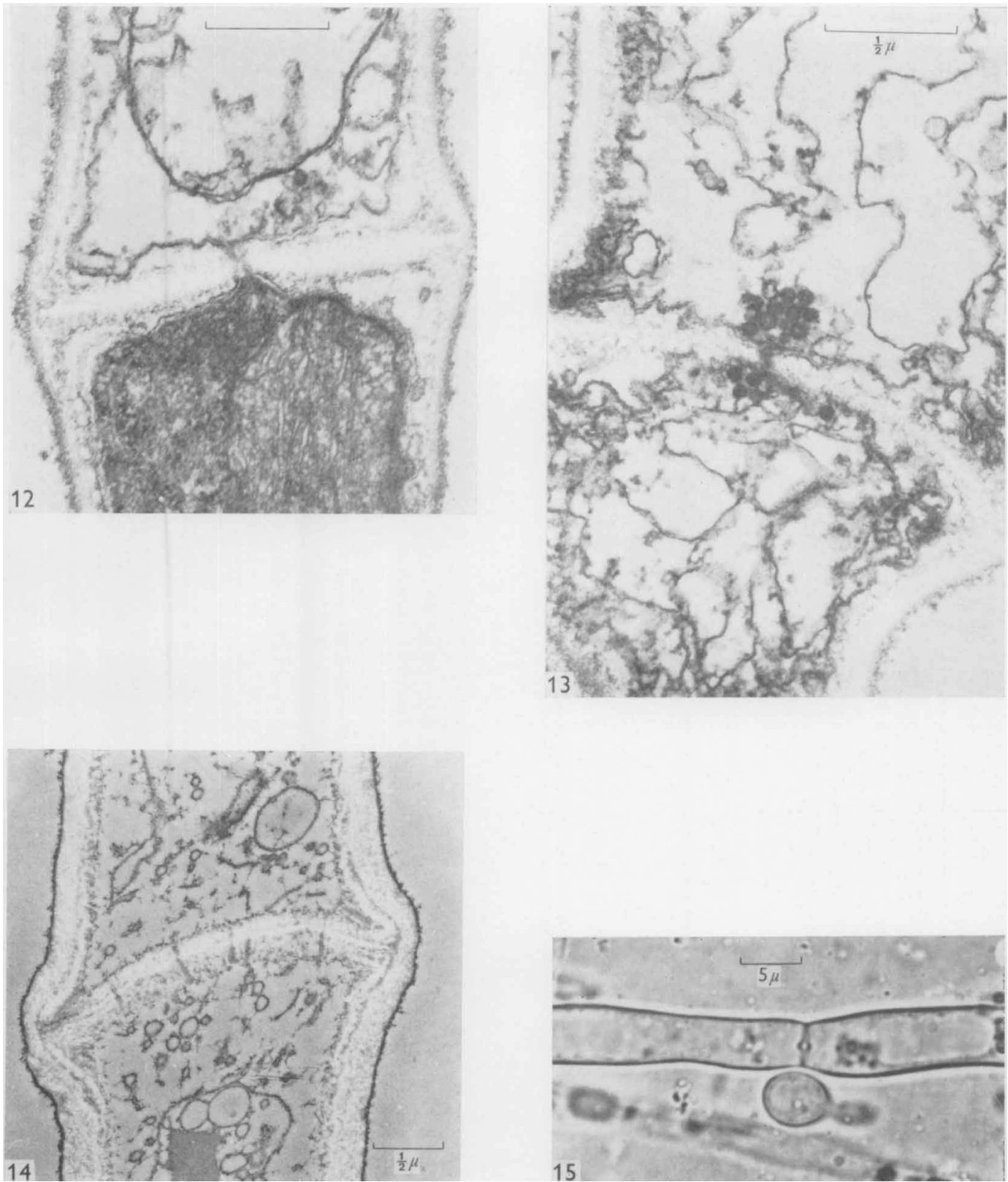

N. J. W. KREGER-VAN RIJ AND M. VEENHUIS 